\title{
エポキシ変性ポリイミド系接着剤の引きはがし強度に及ぼす窒化 アルミニウム基板の表面形状の影響
}

\author{
浅井 博紀*, 岩瀬 暢男*, 須賀 唯知**

\begin{abstract}
Influence of Substrate Surface Shape on Peel-off Strength between Aluminum Nitride Substrates and an Epoxy Modified Polyimide Adhesive
\end{abstract}

Hironori ASAI ${ }^{*}$, Nobuo IWASE* ${ }^{*}$ and Tadatomo SUGA**

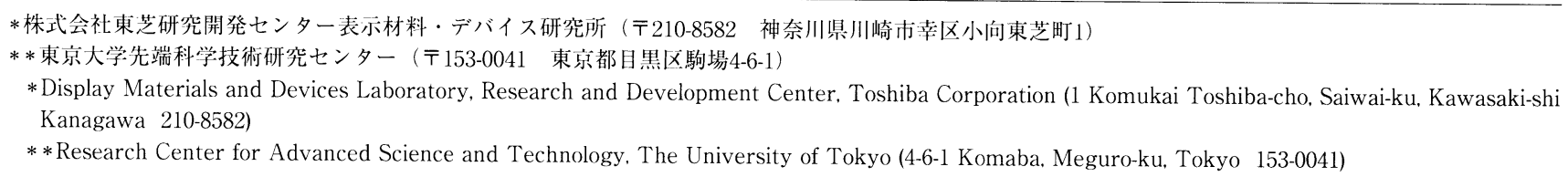

\begin{abstract}
概要 樹脂・窒化アルミニウム（AIN）複合パッケージでは，AIN基板と樹脂部品との接着が重要な要素技術である。本 研究ではエポキシ変性ポリイミド系接着剂に対しAIN基板の表面形状が引きはがし強度に及ほすす影響について報告した。引き はがし強度は表面粗さが粗いほうが接着強度は向上したが, 表面加工力法により向上度は異なった。また, AINが酸素と結び ついて極性基との反応性が向上するような化学的状態に変化することで接着性が向上した。さらに, 基板表面の非極性炭化水 素の割合が低下することも接着性の向上に寄与すると思われる
\end{abstract}

\begin{abstract}
Adhesion between aluminum nitride (AlN) substrates and plastic parts has an important bearing on the development of the plastic and AlN laminated package. This paper reports the influence of surface shape of AlN substrates on peel-off strength between an epoxy modified polyaminobismaleimide adhesive and the substrates. Although peel-off strength increased when the surface became rougher, values differed according to surface treatment method. Surface roughness of each AlN grain, which showed nanometer order, contributes to the increase of peel-off strength. The change of substrate surface to oxidized phase will also contribute to an increase in peel-off strength. Moreover, decrease of non-polar carbon hydride on the substrate surface facilitates an increase in peel-off strength.
\end{abstract}

Key Words: Package, Polyaminobismaleimide, Aluminum Nitride, Peel-off Strength, Surface Roughness

\section{1.はじめに}

半導体素子用パッケージは小型化・薄形化する一方で, パッケージに対する電気特性, 放熱特性の要求も増してき ている"。このうち樹脂パッケージでは，樹脂に低誘電率 材料を用い，導体に銅を使用することで，高い電気特性を 有するパッケージの設計が可能である。また，銅配線もフ オトリソグラフィ法を用いて作製できるため, プリント配

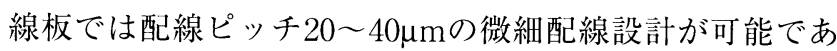
$り^{21.31}$ ，その技術を樹脂パッケージへ転用することが可能で ある。その結果，小型で高密度なパッケージ設計が可能に なる。ところが, 樹脂の熱伝導率は通常 $1 \mathrm{~W} /(\mathrm{m} \cdot \mathrm{K})$ 未満 であるため放熱性に劣る。このため半導体素子の消費電力 が増大すると発生した熱を逃がすためにヒートシンクをつ ける必要が生じ”，パッケージ構造がキャビティダウン構 造になるため小型化することが困難になる。

高熱伝導性セラミックパッケージは高い放熱性を有して おり，キャビティアップ構造とすることでパッケージ構造
を小型にしたまま，半導体素子からの熱をプリント配線板 へ逃がすことが可能であるう。しかし，高熱伝導性セラミ ック材料の誘電率は樹脂ほど低くない。また同時焼成法で 用いられる導体配線材料はモリブデンやタングステンとい った高融点金属材料にフィラーを添加した構成になってい るので，樹脂パッケージにおける銅配線と比べ導体抵抗 が高い。特に微細配線化が進むと配線の高抵抗化が顕著に なる。このため，優れた電気特性を有するパッケージの設 計が複雑になりかねない。

これらの課題をバランスよく解決したパッケージとして 樹脂・セラミックス複合パッケージがあげられるう。この パッケージは電気的に重要な回路部分を低誘電率樹脂フィ ルムと銅で作製する。さらに，この樹脂部品や半導体素子 を支えるために高熱伝導セラミック基板である窒化アルミ ニウム（AlN）基板を用いることで，パッケージ構造はキ ヤビティアップ構造を採用できる。このため，パッケージ の小型化を維持しつつ放熱性を高めることが可能になっ た。このパッケージの製作ではAlN基板と樹脂部品との接 
着が重要な要素技術となっている。金属への接着や樹脂同

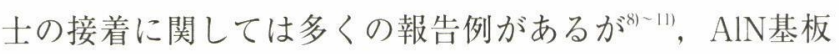
に対する接着特性については報告例がない。特に樹脂・セ ラミックス複合パッケージでは, 接着剤に樹脂流れの良い ものを用いると, 半導体素子搭載部に接着剤が流れ出し, 素子搭載の障害になりやすい。そこで, 本論文では, 樹 脂・AlN複合パッケージに扔いて, 樹脂流れの小さいエポ キシ変性ポリイミド采接着棛の接着特性に対し, AlN基板 の表面形状が及ぼす影響について報告する。

\section{2. 実験方法}

\section{1 基板表面粗さの影響}

樹脂・セラミックス複合パッケージにおいては, 半導体 素子と樹脂基板間のワイヤボンディング性を確保し，七ラ ミック基板の素子搭載面への樹脂の流れ込みを減らす必要 がある。このため, 接着剤にはガラス転移点が高く, 流れ 性の小さなものが求められる。本実験では, エポキシ変性 ポリイミド系接着剤としてガラス転移点が $220^{\circ} \mathrm{C} て ゙$, 樹脂 流れが $3.5 \%$ のエ゚キシ変性ポリアミノビスマレイミド （PABM）接着剤をガラス繊維に塗工したプリプレグ（厚

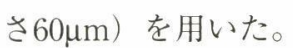

AlN基板には, 焼結助剂として酸化イットリウム $\left(\mathrm{Y}_{2} \mathrm{O}_{3}\right)$ を添加した基板を用いた。基板の熱伝導率は約170W/ $(\mathrm{m} \cdot \mathrm{K})$ である。基板の表面形状を変えるために 2 種類の 加工方法を採用した。一方は, 粒度\#400，600，1000の粒 子を表面に有する平板および鏡面を有する平板に対し，焼 成前のAINグリーンシートを押しつけることにより，平板 の凹凸を転写した状態で焼成した基板（以降プレス基板と 記述）である。もう一方は焼成後の基板を研磨し, 最終仕: 上げを\#400，800，2000，鏡面とした基板（以降研磨基板 と記述）である。

接着強度評価は，引きはがし強度測定によって行った。 Fig. 1 に示すような評価サンプルを作製し，90引きはが し強度試験を実施した。銅簿の厚さは $18 \mu \mathrm{m}$ で, プリント 配線板に用いられる表面処理済みの電解銅箔を用いた。評 価サンプルは， $190^{\circ} \mathrm{C} に$ 加熱したステージ上にAlN基板を 載せ，その上に銅䇴を載せた後，銅䈃とAINセラミック基 板の両方にかかるように接着剤シートを載せ，別の銅䇴を

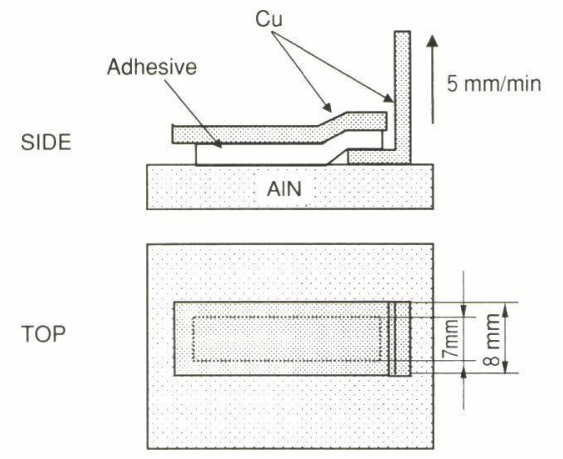

Fig.1 Test piece and peel-off strength test method
接着剂上に載せた後, $2.7 \mathrm{MPa}$ の圧力で 1 軸加圧した。加 圧用ロッドも $190^{\circ} \mathrm{C}$ に加熱してあり，加圧中の温度低下を 防止した。加圧場所は, 接着剂シートと銅簿の位置関係が, 常に一定になるよう位置決めし, 加圧位置の差異が強度の 差異として現れないようにした。引きはがし強度測定は, 銅簿の一端をつかみ 1 軸方向に引っ張った。引張り速度は $5 \mathrm{~mm} / \mathrm{s}$ とした。

\section{2 基板および接着剤表面の表面観察と分析}

プレス基板と研磨基板扔よび接着剂の表面観察は, 走査 型電子顕微鏡（SEM）を用いて実施した。また，断面形 状の測定および基板の表面積測定には非接触表面形状測定 器を用いた。AIN粒子のごく表面の形状については原子間 力顕微鏡 $(\mathrm{AFM})$ を用いて観察した。また，鏡面平板を 押しつけたAlNセラミック基板と\#400研磨した基板に対 してX線光電子分光法（XPS）による表面分析を実施した。 また, PABM接着剤を AlN 基板に触れさせないサンプルと, AlNに触れさせて加熱したサンプルに対しても同様にXPS 分析を実施した。X線源には単結晶分光AIK $\alpha$ 線を用いた。 横軸の補正はC1sを284.6eVとした。

\section{3. 結果と考察}

\section{1 AIN 基板表面形状と接着強度}

Fig. 2 に，400，600，1000抄よび鏡面プレス基板表面 のSEM写真を示した。低倍SEM観察から (Fig. 2-a, c, e,

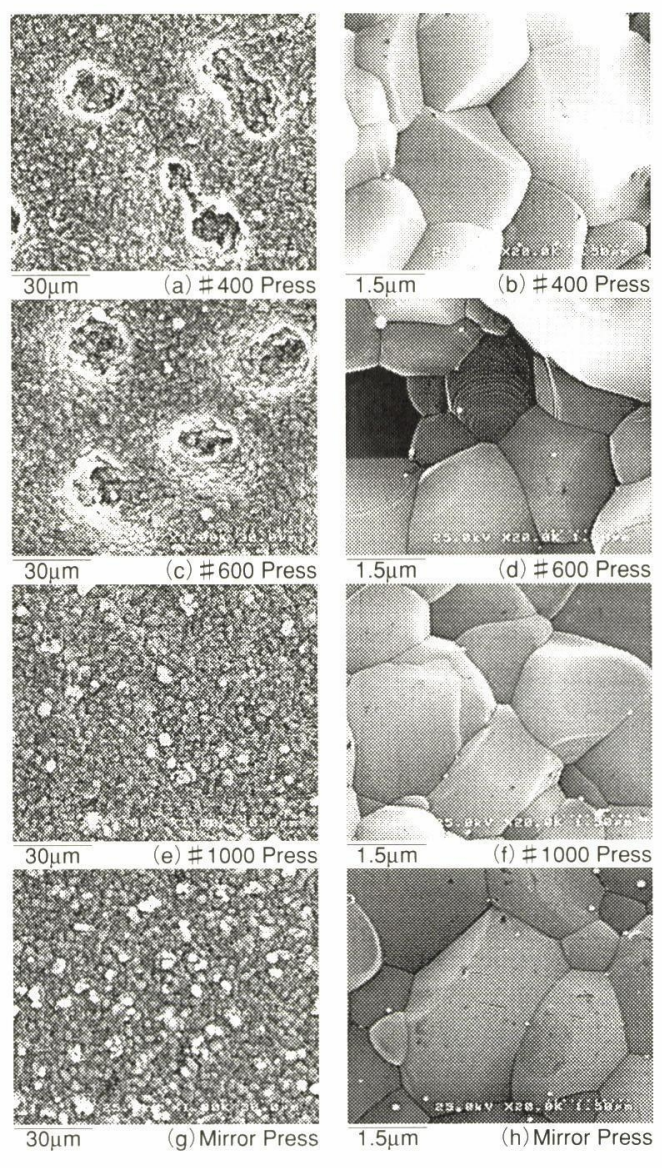

Fig.2 SEM photographs of pressed AIN substrates 
$\mathrm{g}$ 参照), プレス基板の表面にはところどころに篗みがあ り,グリーンシートに押し付けた平板の形状が転写されて いることがわかった。\#400，600プレス基板では容易に山 凸が判別できたが，\#1000プレス基板では必ずしも容易で はなかった。また，鏡面および\#400プレス基板の断面形 状をFig. 3 -a，bに示したが，\#400プレス基板では大きな 凹みを構成するところとそれ以外の部位に分かれている。 同様の結果が\#600プレス基板でも観察された。プレス基 板の大きな凹みは，平均深さが\#400基板では $23 \mu \mathrm{m} ， \# 600$ 基板では $20 \mu \mathrm{m}, \# 1000$ 基板では $6 \mu \mathrm{m}$ であった。また，平 均の穴ピッチは\#400基板では $87 \mu \mathrm{m}, \# 600$ 基板では $83 \mu \mathrm{m}$,

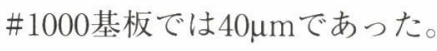

プレス基板を局所的に高倍率で観察すると（Fig. 2 -b, $\mathrm{d}, \mathrm{f}, \mathrm{h}$ 参照), 個々のAlN粒子の外観・粒径は転写した平 板の粗さによらず同等で，一部で粒成長する際の縞模様が 認められるほかは, 全体に平坦な状況を呈していた。また, ところどころに黒色に写っている部分が確認された。これ は，穴の内部も外部も同様であった。叫みの段差部でも粒 界が認められた。Fig. 4 に鏡面プレス基板，\#800，\#2000 および鏡面研磨基板のAFM観察結果の断面像を示した。 Fig. 4 -aから, プレス基板表面を構成するAIN粒子の表面

(a) Mirror press

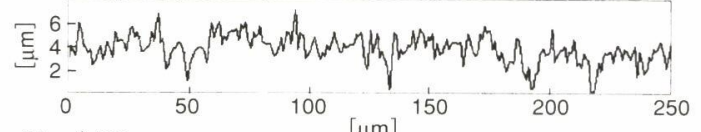

(b) $\$ 400$ press

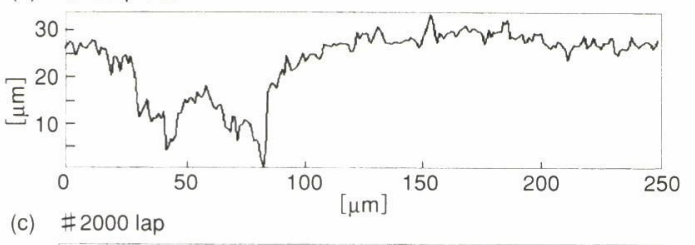

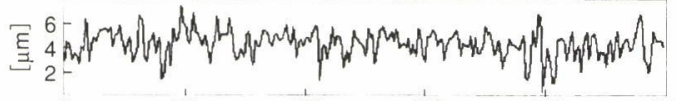

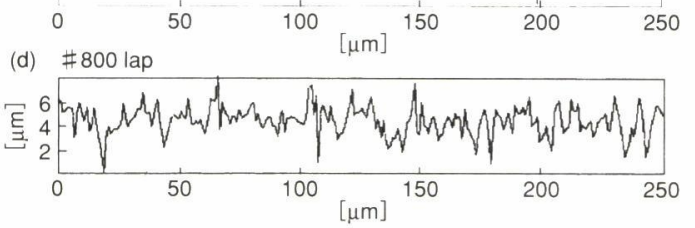

Fig.3 Cross sectional shape of AIN surface

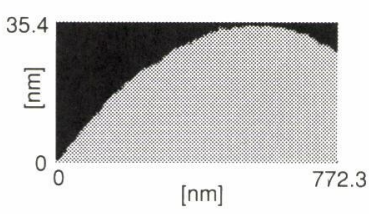

(a) Mirror Press

(c) \#2000 lap

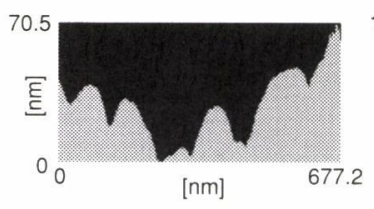

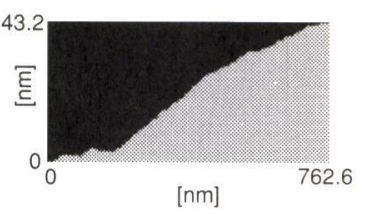

(b) Polishing

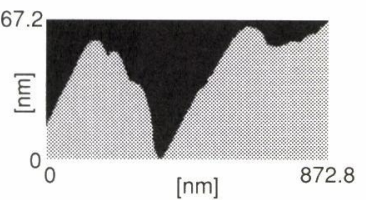

(d) \#800 lap
Fig.4 AFM observation of AIN surface (cross section)
は平坦であることがわかり, 中心線平均粗さは約1.0nmで あった。この平坦性は, 鏡面研磨基板とほぼ同等の平坦性 であつた。

\#400，800，2000ラップおよび鏡面研磨基板の外観を Fig. 5 に示した。低倍SEM観察の結果（Fig. 5 -a， c, e，g 参照)，研磨基板には，\#400，600プレス基板に認められ たような大きな凹みは存在しなかった。また，\#2000およ び\#800研磨基板の断面形状をFig. 3 -c， dに例示したが, 表面の粗さは仕上げ粗さに応じて変化した。高倍SEM像 から (Fig. 5 -b，d，f），鏡面研磨品を除き，粒子表面には 研磨加工による粒内破壊が生じていることがわかる。Fig. 4 -b， c， dは鏡面，\#2000，\#800研磨基板のAFM像を示 すが, 粒子表面には微細な山凸が形成されている。鏡面, \#2000, \#800研磨基板の中心線平均粗さは, それぞれ約 0.6，5.9，11.4nmであった。また，Fig. 4 から，研磨基板 の凹凸のなす角度は, \#400, 800研磨基板で約 $80^{\circ}, \# 2000$ 基板で約 $130^{\circ}$ であった。

これら各種基板上に，PABM接着剤を接着したときの， 引きはがし強度の測定結果をFig. $6 ， 7$ に示した。Fig. 6 は基板最大粗さと強度の関係を示している。また, Fig. 7 はまったく凹凸がない鏡面状態の表面積を 1 としたとき の, 実基板表面の比表面積 (以下, 表面積拡大率と記述) と引きはがし強度との関係を示した。表面積拡大率は, 非 接触形状測定器で表面 $1 \mu \mathrm{m}$ ピッチで測定した結果から,

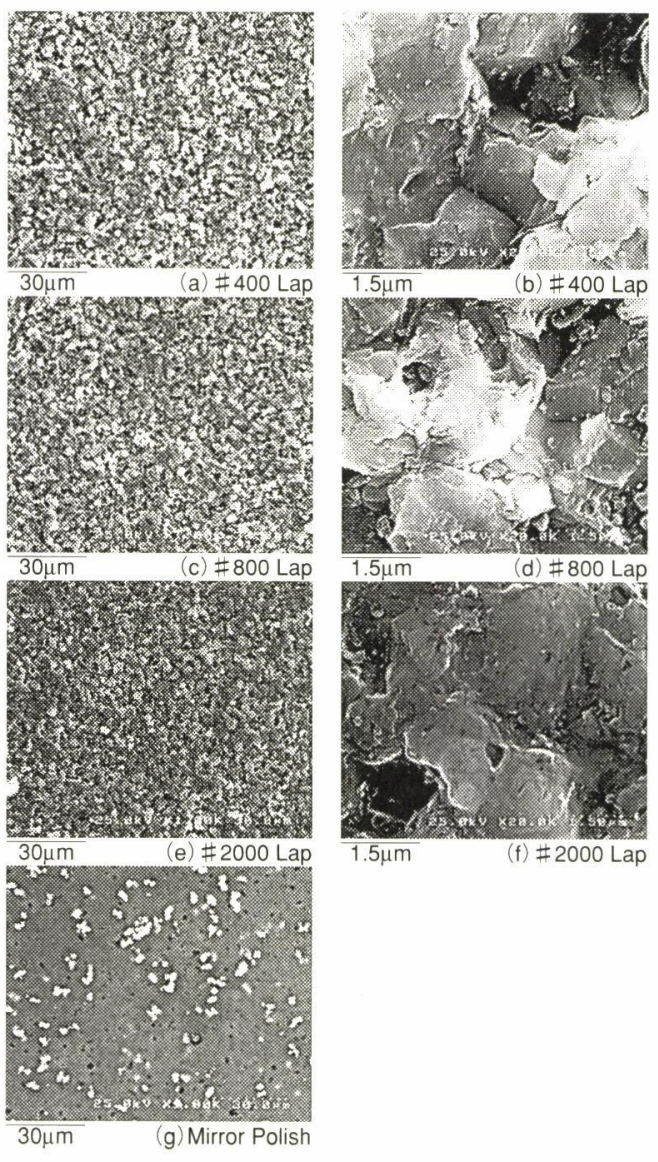

Fig.5 SEM photographs of lapped AIN substrates 


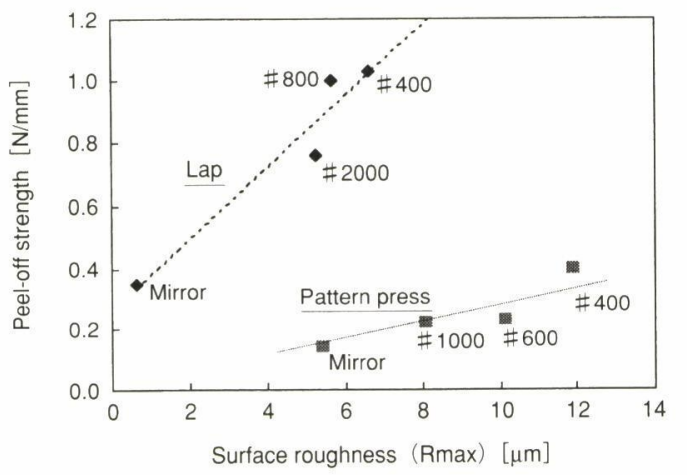

Fig.6 Relationship between surface roughness (Rmax) and

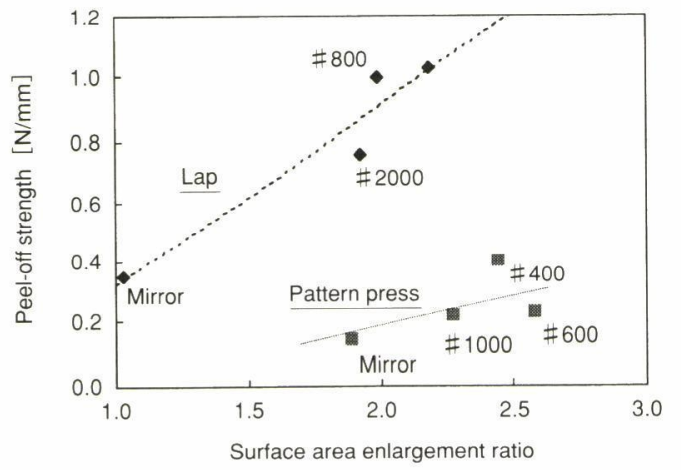

Fig.7 Relationship between surface area enlargement ratio and peel-off strength

表面積を算出した。いずれのグラフでも，加工方法ごとの 近似直線も右上がりとなり，引きはがし強度は，基板表面 粗さが粗い方が, また表面積が広い方が, 引きはがし強度 が強くなる傾向を示した。引きはがし強度は, 表面粗さや 表面積に依存した。しかし, 強度の絶対值は研磨基板の方 がプレス基板よりも高かった。例えば\#400研磨処理品の 強度は $1.03 \mathrm{~N} / \mathrm{mm}$ で, 実用強度 $0.98 \mathrm{~N} / \mathrm{mm}$ 並の強度である のに対し，プレス基板では実用強度に達しなかった。近似 直線の傾きは, 研磨加工の方が大きく, 表面形状の強度へ の依存性は, 研磨加工の方が高かった。ちなみに, 基板へ の接着剤の残留面積は，鏡面研磨で約30\%，\#400，800， 2000研磨基板で約60-70\%であった。

\section{2 PABM接着剂の基板表面への転写性}

AlNプレス基板に接触していたPABM接着剂表面の SEM観察像を, プレス基板表面の同倍率の写真と共にFig. 8 に示した。全般的に，PABM接着剤表面にAIN基板表面 の凹凸が良好に転写されている。観察倍率を上げたときの， PABM接着剂の表面および断面方向のSEM像をFig. 9 に示 した。図から\#400プレス基板で認められた平均深さ $23 \mu \mathrm{m}$ 程度の凹み部分では, 凸部高さが約 $10 \mu \mathrm{m}$ 末満であり, プ レス基板深さ寉みよりも低い凸部しか得られていなかっ た。Fig.10は, AlN粒子表面の細かな形状のPABM接着郕 への転写性のSEM観察結果を示しているが, PABM接着 剤表面にAlN粒子表面の形状が，良好に転写されている。 これらは, PABM接着郕が, 粒子表面の数十 $\mathrm{nm}$ 程度の微 細な山凸に対しては，転写性が良好である一方で，樹脂流

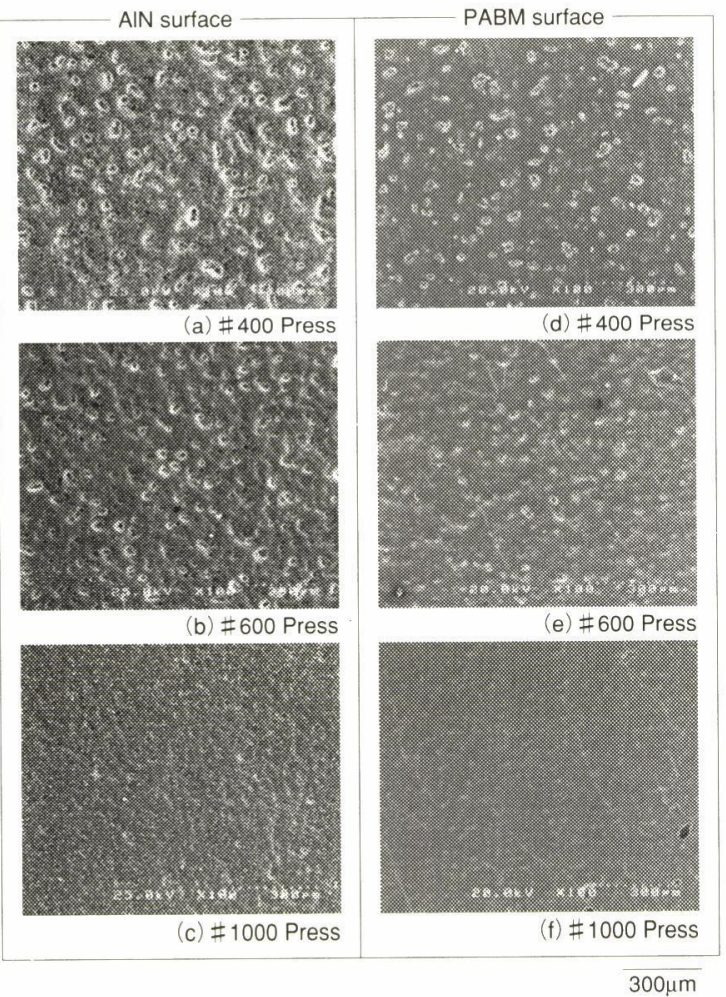

Fig.8 SEM photographs of surface of AIN pressed substrates and PABM adhesives

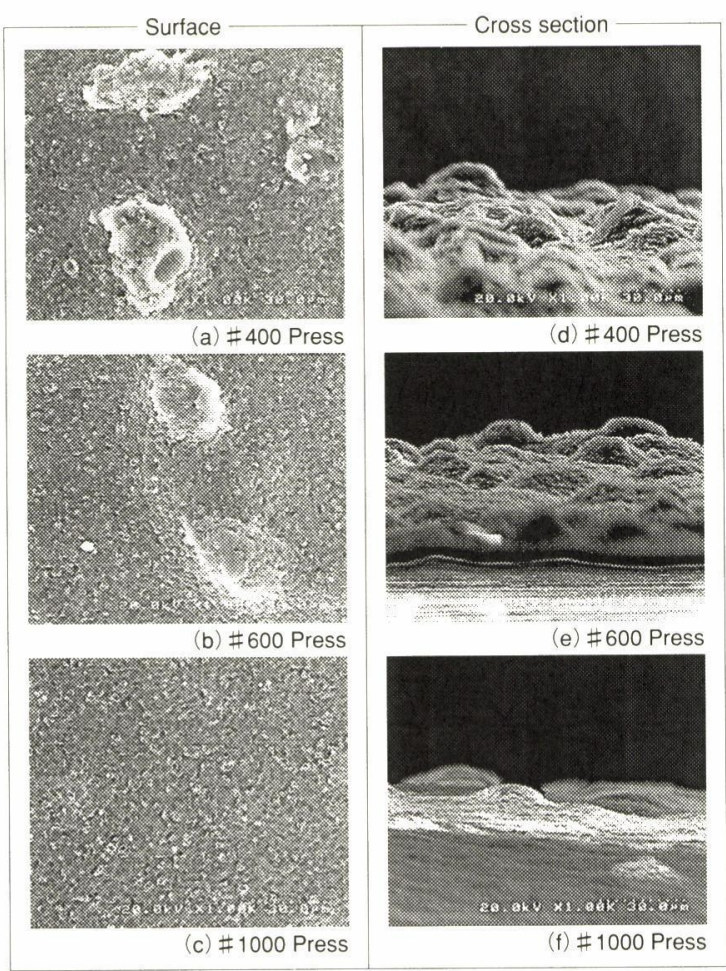

$30 \mu \mathrm{m}$

Fig.9 SEM photographs of surface and cross section of PABM adhesives

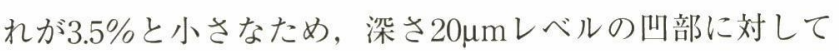
は十分に流れ込めなかったためと推察される。また，プレ ス基板表面では粒子表面が中心線粗さ約 $1.0 \mathrm{~nm}$ と平坦であ るばかりでなく, 粒子同士が表面で約 $120^{\circ}$ の角度で交わっ ていることがAFMから判明していることから，粒界でい 


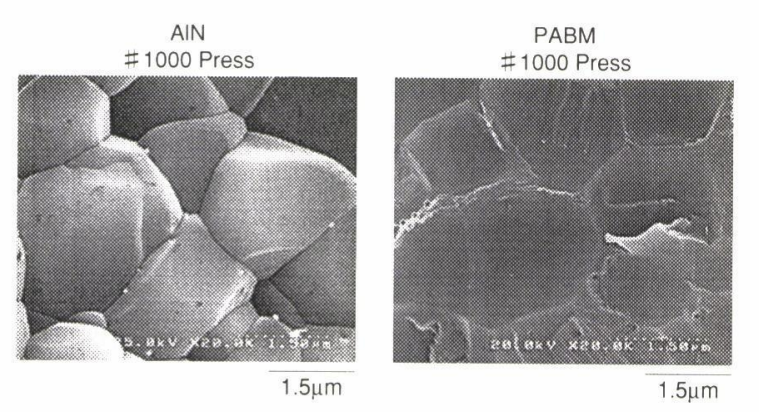

Fig.10 SEM photographs of AIN grains and PABM adhesives

わゆるアンカー効果を得ることが困難な構造になっている と考えられる。一方, 鏡面研磨基板を除く研磨基板では, 粒子上に中心線粗さ数十 $\mathrm{nm}$ 程度の微細な凹凸があり，ま た基板表面の凹凸も3-5 $\mu \mathrm{m}$ 程度であることから，樹脂流れ の小さなPABM接着剤でも十分に山凸に浸入できたと考 えられる。微小凹凸が接着強度を向上させる効果は, 金属 への接着強度を向上させる祭にも認められていることから ${ }^{124}$, PABM接着剤が十分流れ込むことができれば，AINセラミ ックスの場合も同様に, 微小凹凸が引きはがし強度を向上 させることに寄与すると考えられる。

\section{3 AIN基板表面分析結果}

AIN基板表面のXPS分析結果をFig.11に示した。(a)は $\mathrm{Al} 2 \mathrm{p} ，(\mathrm{~b})$ は $1 \mathrm{~s} ，(\mathrm{c})$ は C $1 \mathrm{~s} の$ 分析結果を示した。また, Table 1 に各成分元素原子数のアルミニウム原子数に対す る比を記載した。

$\mathrm{A} 12 \mathrm{p}$ のピークを比較すると, プレス基板のピーク位置 と研磨基板のピーク位置では, 研磨基板のピークが高エネ ルギ結合側に $0.5 \mathrm{eV}$ 程度シフトしていた。半值幅も研磨基 板の方が0.5eVほど大きかった。またTable 1 から, N/Al が0.51と 1 からかなり離れていたことも考虑に入れると， このシフトは, Alが電気院性度の大きな酸素と結合し, 酸化された方向にシフトした可能性を示すものと思われ る。AlNは比較的水分と反応しゃすく, 原料粉末の水中で の分解 ${ }^{(3)}$ や水蒸気䨌囲気中での水酸化物生成が報告されて いる ${ }^{14)}$ 。研磨工程でも, AIN表面に酸化物や水酸化物が形

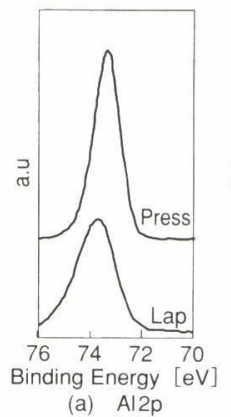

(a) $\mathrm{Al} 2 \mathrm{p}$

Fig.11

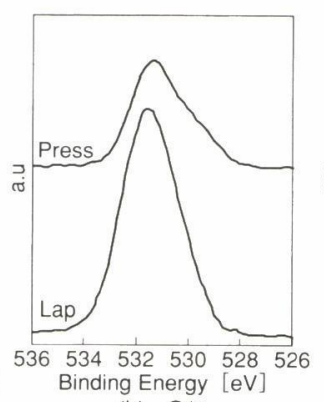

(b) $01 \mathrm{~s}$

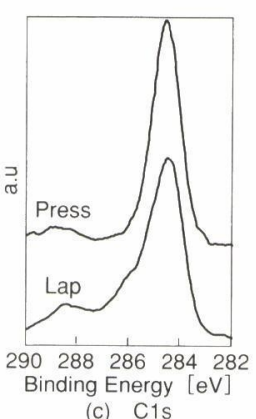

(c) $\mathrm{C} 1 \mathrm{~s}$
Table 1. Atomicity ratio $(1 / \mathrm{Al})$

\begin{tabular}{l|c|c|c|c|c|c|c|c}
\hline & $\mathrm{Al}$ & $\mathrm{N}$ & $\mathrm{O}$ & $\mathrm{C}$ & $\mathrm{Y}$ & $\mathrm{B}$ & $\mathrm{Ca}$ & $\mathrm{Si}$ \\
\hline \#400 lapped & 1.00 & 0.51 & 1.52 & 1.34 & 0.02 & - & - & 0.03 \\
\hline Mirror pressed & 1.00 & 0.77 & 0.50 & 0.79 & 0.05 & 0.05 & 0.04 & - \\
\hline
\end{tabular}

成したものと推察される。一般に, 金属と有機接着剤の接 着の際には，金属表面の酸化物や水酸化物が接着性に大き く寄与していると考えられているが，AlN基板表面におい ても, アルミニウムの酸化物や水酸化物が, 接着性の向上 に寄与しているものと思われる。

O1sピークを比較すると, プレス基板も研磨基板も，半 值幅が広く単一ピークではないと推察されるが, ピークを 分離して個々の結合状態を特定することはできなかった。 酸素原子数の $\mathrm{Al}$ 原子数に刘する比では, 研磨基板の方が プレス基板よりも約 3 倍多い酸素が検出された。酸素原子 数の増加は, AIN基板が研磨によって酸化されたことを示 唆するものと考えられる。

C $1 \mathrm{~s}$ ピークを比較すると, プレス基板も研磨基板とでは, 酸素と結びついた高エネルギ側でピーク形状が異なってい た。C1sピークを分割し, 分割したピークに対応する結合 形態の占める割合をTable 2 に示した。プレス基板表面に は, 非極性の炭化水素の結合状態が87\%を占めるのに対し, 研磨基板では67\%であった。酸素と結びついた高エネルギ 側のピーク面積は, 研磨基板の方がプレス基板よりも2.5 倍多かった。PABM接着剂の接着性に寄与する官能基と して, 水酸基, エポキシ基, アミノ基, カルボニル基等が 考えられるが, いずれも極性を有する有機物と反応しやす い。このため, AlN基板表面の炭素原子が, C-Oのように 極性を示すような結合形態で存在している比率が高いと, AIN基板とPABM接着剤の接着性は向上するものと考えら れる。このように, 基板表面のAlN基板の酸化状態, 炭素 原子が極性を有する結合形態で存在している構成比率の違 いといった化学状態の差も, 接着強度の違いに寄与したも のと推察される。

\section{4 PABM接着剂とAIN基板との接着}

AIN基板に触れさせることなく加熱したPABM接着剂表 面と, 鏡面プレス基板表面に触れさせたPABM接着剤表 面のN1sのXPS分析結果をFig.12に示した。AINに接触し ていなかったサンプルでは, アミン等に帰属されると推測

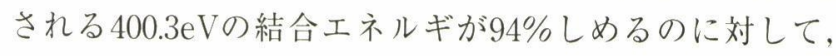
AlNと接していたサンプルでは $400.3 \mathrm{eV}$ ヒピークは $64 \% に$ 減少し, $398.3 \mathrm{eV}$ のピークが増加した。同様の現象として, ポリイミドフィルム表面に銅を蒸着させると同時に窒素イ オンを照射する場合, 窒素の照射量が増加するにつれて, $400.4 \mathrm{eV}$ イミド結合が約 $398 \mathrm{eV}$ のC-N結合に相当するピー クにシフトしていくことが報告されている゙の。本実験では $398.3 \mathrm{eV}$ の化学状態を特定できなかったが, PABM接着剂 の窒素がAINとの接触により, 窒素イオン照射実験と同様

Table 2. Smoothing results for $\mathrm{Cls}$ peak [\%]

\begin{tabular}{l|c|c|c|c|c}
\hline & $\mathrm{CO}_{3}{ }^{2-}$ & $\mathrm{COO}$ & $\mathrm{C}=\mathrm{O}$ & $\mathrm{C}-\mathrm{O}$ & $\mathrm{CHx}$ \\
\hline \#400 lapped & - & 9 & 6 & 18 & 67 \\
\hline Mirror pressed & 3 & 6 & 1 & 4 & 87 \\
\hline
\end{tabular}




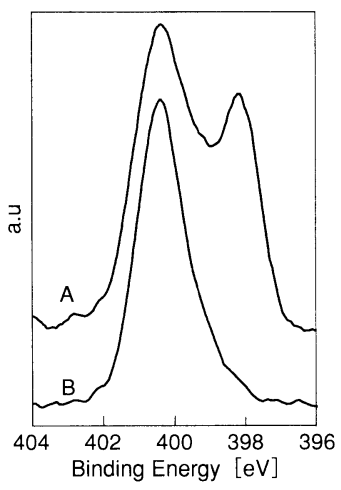

Fig.12 XPS N1s spectra of PABM surface; $A$ is PABM which contacted on AIN substrates and $B$ is PABM which did not contact on AIN substrates

Table 3. Atomicity ratio $(1 / \mathrm{C})$

\begin{tabular}{l|c|c|c|c|c|c|c}
\hline & $\mathrm{O}$ & $\mathrm{N}$ & $\mathrm{Br}$ & $\mathrm{Si}$ & $\mathrm{S}$ & $\mathrm{Al}$ & $\mathrm{Y}$ \\
\hline AlN contact & 0.22 & 0.07 & 0.011 & 0.003 & 0.002 & 0.002 & 0.0005 \\
\hline Non contact & 0.20 & 0.05 & 0.017 & 0.007 & 0.001 & - & - \\
\hline
\end{tabular}

のことが生じ，アミン形成よりも電気陰性度の小さな原 子・分子等と結合して変化したと思われる。

Table 3 は，AlN基板に触れさせることなく加熱した PABM接着剤表面と, 鏡面プレス基板表面に触れさせた PABM接着剤表面の各成分元素原子数の炭素原子数に対 する比を示している。AlNと接触させた接着剤表面からは, 微量に $\mathrm{Al}$, Yが検出されている。鏡面プレス基板と $\mathrm{PABM}$ 接着剂との接着強度が弱く, 接着剂表面には, AlN基板か らの脱粒は観察されなかった。Al原子は，AIN，AlN表面 が酸化した酸化アルミニウムあるいは，粒界構成相である イットリウムアルミネートの状態で存在していると考えら れる。Fig.10-(a)のAl2pのピークからは, Al-N, Al-O (AlOピークはAl-Nピークにほぼ重なる）以外のピークを検出 できていない。しかし, AlNと接触させた接着剤表面から $\mathrm{Al}$ ，Yが検出されたことは，鏡面プレス基板表面に，AlN 粒子との接合強度が低いAlとYを含む層が形成されていた 可能性を示唆している。

\section{5 引きはがし強度における化学的な接着成分}

Fig. 7 で, プレス基板と研磨基板の引きはがし強度を比 較すると, 同じ表面積拡大率であるのに引きはがし強度が 異なった。例えば，鏡面プレス基板と\#2000研磨品では, 前者の引きはがし強度が $0.98 \mathrm{~N} / \mathrm{mm}$, 後者の引きはがし強 度が $0.78 \mathrm{~N} / \mathrm{mm}$ であった。図から，プレス基板での引きは がし強度が，表面積拡大率を 1 に近づけると引きはがし強 度が 0 に近づくと予想される。また，XPS分析の結果，プ レス基板の表面には, 炭素が炭化水素として多く存在して おり，PABM接着剤との接着性が良くないと予想される ことから, PABM接着剤とAINプレス基板との化学的な接 着力は弱いと考えることができる。したがって, 研磨基板 の表面積拡大率を 1 に近づけたときの引きはがし強度約 $0.34 \mathrm{~N} / \mathrm{mm}$ m, 表面皘効果を除いたときの研磨基板と PABM接着剤との化学的な接着による引きはがし強度に
該当するものと思われる。表面積拡大率 1 のときの引きは がし強度は, 表面積にのみ引きはがし強度が依存する, と 仮定した場合のグラフの傾きに相当する。したがって, Fig. 7 で，プレス基板と研磨基板の表面積拡大率に対する 依存の傾きが異なっているが, その主要因は, 化学的な接 着の差異によるものである。

\section{6 引きはがし強度と基板表面形状}

接着剤の寸法が一定のときに, 引きはがし強度を化学的 な接着による強度成分と, 形状による強度成分に分離でき ると仮定する。接着による強度とは, AlNと接着剂が接触 し，ファンデルワールスカ等も含めた化学的な結合によっ て接着していることによって生じる強度を示し，形状によ る強度とは, 両者に何らの接着力がなくても, 例えば Hallingらが摩擦力の解析で用いたくさび状突起が噛み合

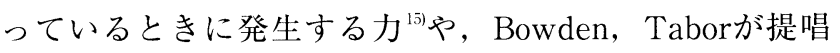
した溝掘りの力荓等による強度測定時の抵抗力を示す。上 記を式で表すと，

$\mathrm{Fp}=\mathrm{Fa}+\mathrm{Fm}$

ここで，Fpは引きはがし強度，Faは接着による強度，Fm は測定時の抵抗力である。Faは接触している界面間での 接着によるので, 接触面積と界面の接着力との積で表され る。一方, Fmは, 引きはがし強度測定時に摩擦力を生じ させる荷重成分と, 接着剤と基板間の摩擦係数の積で示す ことができると考える。これより，

$\mathrm{Fa}=\mathrm{S} \cdot \mathrm{Wa}$

$\mathrm{Fm}=\mu \cdot \mathrm{W}$

ここで, Sは接触している物質界面の面積, Waは接触し ている物質界面の単位面積当たりの接着力, $\mu$ は接着剂と 基板面の摩擦係数, Wは引きはがし強度測定時に摩擦力を 生じさせる荷重成分である。

研磨基板では最終仕上げ砥粒のサイズが異なる以外はほ ぼ同一の工程を経ることから，Waがほぼ一定であろうと 仮定する。基板表面にほとんど凹凸を有しない鏡面研磨基 板の引きはがし強度を基準とし, 引きはがし強度が, 単純 に表面積だけに比例すると仮定すると，\#2000研磨基板が, 予想值に近い数值を示すのに対し，\#400，800研磨基板の 引きはがし強度は, 予想值よりも大きな值を示している。 Fig. 5 のSEM観察結果や, Fig. 3 の断面形状からは, \#800 研磨基板表面には粒子内の刍裂や複雑で深い溝が形成され ているのに対し，\#2000研磨基板は微小な突起はあるもの の, 全体的に滑らかな様相を呈している。また, Fig.4の AFM観察の結果, \#2000研磨基板の溝の角度が約 $130^{\circ}$ で あるのに対し，\#800では約 $80^{\circ}$ であった。 \#400についても 同様に約 $80^{\circ}$ であった。Hallingが溝掘り抵抗力が発生する ときの単純化したモデル ${ }^{15}$ では, 摩擦係数 $(\mu)$ は

$$
\begin{aligned}
& \mu=(2 / \pi) \cot (\theta / 2) \\
& \theta \cdots \text { 溝の角度 }
\end{aligned}
$$

で表されるとしている。これをAlN粒子表面の凹凸に当て 
はめると，\#2000研磨基板では摩擦係数が $0.3, \# 400,800$ 研磨基板では0.8となる。したがって，\#400，800研磨基板 で引きはがし強度測定時に発生する抵抗力は, \#2000研磨 基板よりも大きくなると推察され，これが，研磨基板にお ける引きはがし強度差として現れるのではないかと思われ る。また, 実際の接着剂の厚さは, 表面の山凸の影響で一 定ではないが, 接着剤が薄いときには, 引きはがしに必要 な仕事量が, 接着剤厚さに依存することが報告されている \#2000研磨基板と\#400, 800研磨基板とでは, Fig. 6 やFig. 3 に示したように凹凸の深さが異なり，後者の方が深い。 このことも，\#2000研磨基板よりも\#400，800研磨基板の 方が引きはがし強度が大きかったことにつながったと思わ れる。

\section{4. まとめ}

AlN基板と流れ性の低いPABM接着剤との引きはがし強 度に及ぼす基板の表面形状の影響について実験した。基板 の表面粗さが粗いほど引きはがし強度は向上した。また表 面積が大きな方が，引きはがし強度は向上した。引きはが し強度の向上は，基板表面の凹凸を焼成前に形成してから 焼成するか, 焼成後に研磨によって形成するかにより向上 度は異なり, 研磨による引きはがし強度の方が大きかった。 PABM接着剂はAIN基板表面に対して良好な転写性を示し たが，樹脂流れが低いために表面の $10 \mu \mathrm{m}$ 程度の深さまで しか入り込めなかった。また, XPS分析の結果, 基板の加 工方法で表面の化学状態が異なった。基板表面が酸化した り，基板表面の炭素が酸素と結びついて極性を示すような 化学状態になると, 接着性が向上するものと思われる。接 着の際に接着剤表面の窒素の化学状態が変化したが, この ことも強度の向上に寄与した可能性がある。

\section{謝 辞}

この実験を遂行するにあたり，東芝ディスプレイ・部品 材料社の五代儀 靖氏に試料準備でお世話になりましたこ とをここに感謝いたします。

(2000.2.17-受理２000.5.19-再受理）

\section{文献}

1) B.Siu: "The Blurring Boundaries of VLSI and System Packaging”, Proc. IEMT/IMC 1997, pp.1-4, 1997

2) Y.Takazaki : "Technology Trend of Build-up Printed Wiring Board”, J. Jpn. Inst. Electron. Packg., Vol.2, No.6, pp.450-453, 1999

3) T.Shimoto, K.Matsui, K.Kikuchi, Y.Shimada, and K. Utsumi : "New High-Density Multilayer Technology on PCB”, IEEE, Trans. Adv. Packg, Vol.22, No.2, pp.116-122, 1999

4) B.Lynch, C.Mattei, and V.DiCaprio: "A Thermal and
Electrical Enhanced Low Cost Ball Grid Array Package", Proc. Pan Pacific Microelectronics Symposium 1997, pp.425-440, 1997

5) N.Iwase, K.Yano, H.Asai, J.Monma, T.Yasumoto and M.Mukai : "Thermal Resistance Improvement Utilizing a PWB for a Thin AIN BGA Package with No Cooling Fin", Proc. INTERACK'97, EEP-Vol.19-2, pp.2169-2172, 1997

6) A. Horiguchi, Y.Sato, F.Ueno, N.Iwase, A.Tsuge, and T.Takahashi: "Tungsten Conductor Behavior in an Aluminum Nitride Tungsten Co-fired System”, MRS Int'l. Mtg. On Adv. Mats., Vol.10, pp. 185-195, 1989

7) H.Asai, K.Yano, K.Iyogi, N.Iwase and T.Fujiwara : "Design and Characteristics of a Newly Developed Cavity-up Plastic and Ceramic Laminated Thin BGA Package", IEEE Trans. Adv. Packg., Vol.22, No.3, pp.460-467, 1999

8) N.Chou, D.Dong, J.Kim, and A.Lin : “An XPS and TEM Study of Intrinsic Adhesion between Polyimide and $\mathrm{Cr}$ Films”, J. Electrochem. Soc., 131, pp.2335-2340, 1984

9) S.Freilich and F.Ohuchi: "Reactions at the PolyimideMetal Interface”, Polymer, Vol.28, pp.1908-1914, 1987

10) N.Inagaki, S.Tasaka and M.Masumoto: "Plasma Graft Polymerization of Vinylimidazole onto Kapton Film Surface for Improvement of Adhesion between Kapton Film and Copper", J Appl. Polym. Sci., Vol.56, pp.135-145, 1995

11) Y.Tabata, T.Ashida: "Adhesion Properties of AcrylicParticle-modified Epoxy Adhesives for Aluminum Materials”, J. Adhe. Soc. Jpn., Vol.34, No.11, pp.425-431, 1998

12) J.Venables, D.Mcnamara, J.Chen, T.Sun, and R. Hopping : "Oxide Morphologies on Aluminum Prepared for Adhesive Bonding”, Appl. Surf. Sci. Vol.3, pp.88-98, 1979

13) P.Bowen, J.Highfeld, A.Mocellin and T.Ring : "Degradation of Aluminum Nitride Powder in an Aqueous Environment”, J. Am. Ceram. Soc. Vol.73, No.3, pp.724-728, 1990

14) Y.Kurihara, T.Endoh and K.Yamada: "The Influence of Moisture on Surface Properties and Insulation Characteristics of AIN Substrate", IEEE Trans. CHMT, Vol.12, No.3, pp.330-334, 1989

15) 松永正久, 訳, J.Halling: “トライボロジ”, 近代科学社, p.83-87, 1984

16) 曽田範宗, 訳, F.Bowden and D.Tabor： “固体の摩擦と潤 滑”, 丸善p.82, 1962

17) T.Igarashi: "Mechanics of Peeling of Rubbery Materials. I. Peel Strength and Energy Dissipation", J. Polym. Sci. , Vol.13, pp.2129-2134, 1975 